\title{
The Effect of Nano Tio and Nano Boron Nitride on Mechanical, Morphological and Thermal Properties of WF/PP Composites
}

\section{Utjecaj nanočestica titanova dioksida i nanočestica boron nitrida na mehanička, morfološka i toplinska svojstva WF/PP kompozita}

\author{
Original scientific paper • Izvorni znanstveni rad \\ Received-prispjelo: 5. 4. 2017. \\ Accepted-prihvaćeno: 21. 2. 2018. \\ UDK: $630 * 863.2$ \\ doi:10.5552/drind.2018.1724
}

\begin{abstract}
This study evaluated the effect of nano boron nitride (BN) and nano titanium dioxide (TiO ${ }_{2}$ ) on some physical, mechanical and thermal properties of WF/PP composites. Polyproplene as a polymer matrix and wood flour obtained from particleboards were used as reinforcing fillers to prepare the composites by using a single screw extruder. It was observed that density in all composites did not change significantly with the increasing of wood flour. It was found that BMOR and BMOE of the composites increased with the increasing of the wood flour content and nanoparticle types, while the TMOR and TMOE decreased. According to the results of thermal properties (TGA), thermal degradation of all composites was found to be lower compared with pure PP.
\end{abstract}

Keywords: wood polymer composites, natural fillers, nanoparticle type, characterization analysis

SAŽETAK • U radu je predočeno istraživanje utjecaja nanočestica borova nitrida (BN) $i$ nanočestica titanova dioksida ( $\mathrm{TiO}_{2}$ ) na neka fizikalna, mehanička i toplinska svojstva drvno-plastičnih kompozita (WF/PP kompozita). Za proizvodnju kompozita upotrijebljeni su polipropilen kao polimerna matrica i drvno brašno dobiveno od ploča iverica kao punilo, uz pomoć jednovijčanog ekstrudera. Uočeno je da se gustoća kompozita ne mijenja značajno s povećanjem količine drvnog brašna. Utvrđeno je da se BMOR i BMOE kompozita povećava s povećanjem sadržaja drvnog brašna i nanočestica TiO $i$ BN-a, dok se TMOR i TMOE smanjuju. Prema rezultatima istraživanja toplinskih svojstava (TGA), zaključeno je da je toplinska degradacija svih istraživanih kompozita manja u usporedbi s čistim polipropilenom.

Ključne riječi: drvno-plastični kompoziti, prirodna punila, vrsta nanočestica, analiza svojstava

\footnotetext{
${ }^{1}$ Authors are assistant and associated professor at Department of Forest Industrial Engineering, Faculty of Forestry, Bartin University, Bartin, Turkey. ${ }^{2}$ Author is lecturer at Caycuma Vocational School, Department of Material and Material Processing Technology, Bulent Ecevit University, Caycuma/Zonguldak, Turkey.

${ }^{1}$ Autori su asistent i izvanredni profesor Odjela za industriju baziranu na šumi, Šumarski fakultet, Sveučilište u Bartinu, Bartin, Turska. ${ }^{2}$ Autor je predavač Sveučilišta Bulent Ecevit, Strukovna škola Caycuma, Program za namještaj i dekoracije, Zonguldak, Turska.
} 


\section{INTRODUCTION}

\section{UVOD}

Wood-plastic composites (WPCs) are principally concerned with thermoplastic polymers reinforced by wood and wood derivatives such as fibers or flour (Soccalingame et al., 2016). Wood flour (WF) actually represented a waste material, which had to be eliminated from sawmills in the past. Many waste utilization strategies have been introduced over the last century, such as bedding, composting, combustion, gas generation, use as feedstock for chemical industry, etc. Among them, the use of WF as raw material for making new solids is the most positive due to its convenience in application and low energy costs (Ashori, 2008; Okamoto, 2003).

In general, wood flour is used as plastic filler, which tends to increase the stiffness of the composite but does not improve its strength. Natural fibers can be used to reinforce plastics rather than filler rate, which increases strength as well as stiffness. Natural fibers can be used to reinforce filled plastics, by increasing both strength and stiffness. Wood and other lignocellulosic fibers typically have higher particle sizes than those of wood flour (Osswald and Menges, 1995). WPCs combine the best properties of the pure components and can show superior performance in many application areas. Compared with potential traditional competitors, WPCs offer better thermal and acoustic isolation than aluminum, better durability and lower maintenance than wood, and often lower price than pure plastics (Garcia et al., 2009).

Lignocellulosic materials have made significant contributions to the thermoplastic industry, which has led to the emergence of wood-plastic composites in the construction industry. Products such as decking, fencing, siding, window framing, and roof tiles are being introduced into the market. The use of WPCs is also increasing in construction, transportation, industrial and consumer industries. Growing interest in renewable resources-based products is due to social and environmental concerns. Commercial thermoplastics such as polyethylene (PE), polypropylene (PP), polyvinyl chloride (PVC), polystyrene (PS), and styrene maleic anhydride (SMA) are commonly used in the manufacture of plastic/wood fiber composites (Sobczak et al., 2013; Bledzki and Gassan, 1999; Rowell et al., 1997; Zor et al., 2016). The use of technical and standard plastics has approached the application of natural fibers thanks to their low prices and steadily rising performance (Wittig, 1994). The composites reinforced with wood have shown a great growth due to many advantages. Their processing is easy, economic, and ecological. They have relatively high strength and stiffness, low cost, low density, low $\mathrm{CO}_{2}$ emission, and they are biodegradable and renewable (Deka and Maji, 2011). However, these polymers have low thermal conductivities. Therefore, some researchers have worked to improve the thermal conductivity and electrical insulation of polymers by adding different fillers and fire retardants.
Boron nitride $(\mathrm{BN})$ has been widely used in the thermal management industry for years. $\mathrm{BN}$ is a good lubricant and abrasive, and it has a high thermal conductivity, high electrical resistance, and high temperature resistance. The familiar structures of $\mathrm{BN}$ are the hexagonal $(\mathrm{hBN})$ and cubic $(\mathrm{cBN})$ crystal structures. The structure of hBN is more stable than that of $\mathrm{cBN}(\mathrm{Me}-$ neghetti et al., 2008). BN is a low atomic numbered nonmetallic compound; its melting temperature $\left(\sim 3000{ }^{\circ} \mathrm{C}\right)$ is too high to be used for thermal insulation. BN/polymer composites can decrease thermal expansion and increase thermal conductivity, while enhancing the electrical insulation properties (Zhou et al., 2007). Also, the addition of a small amount of BN in polymers might enhance their extrusion by increasing their flowablity (Jung et al., 2010). Nano $\mathrm{TiO}_{2}$ particle is one of the promising inorganic nano fillers used in polymer matrix composites to enhance the mechanical properties (Nayak et al., 2016; Bardak et al., 2016). Among the investigated inorganic nano fillers, $\mathrm{TiO}_{2}$ nanopowder is being increasingly investigated because it is non-toxic, chemically inert, low cost, corrosion resistant and has a high refractive index, UV filtration capacity and high hardness (Mirabedini et al., 2008).

The goal of this research was to investigate the usability of wood flour obtained from particleboards in wood plastic composites. Furthermore, the effects of nano $\mathrm{TiO}_{2}$ and nano $\mathrm{BN}$ on the physical, mechanical and thermal properties of WF/PP composites have determined.

\section{MATERIAL AND METHODS}

2. MATERIJAL I METODE

\subsection{Materials}

2.1. Materijali

Wood flours (WF) were supplied by Kastamonu Entegre Ağaç Sanayi A.Ş. Wood flours consist of $50 \%$ Gymnospermae (Pinus nigra Arn. and Pinus sylvestris L.) wood and $50 \%$ Angiospermae wood (Fagus orientalis L. and Populus alba L.). Oven-dry densities of WFs used in the study were $0.54 \mathrm{~g} \cdot \mathrm{cm}^{-3}, 0.48 \mathrm{~g} \cdot \mathrm{cm}^{-3}$, $0.63 \mathrm{~g} \cdot \mathrm{cm}^{-3}$ and $0.40 \mathrm{~g} \cdot \mathrm{cm}^{-3}$, respectively. All WF samples were of the same size made using $0.5 \mathrm{~mm}$ sieve. Polypropylene (EH241) was supplied by PETKIM Inc, in Turkey. The properties of the PP - EH241 are listed in Table 1.

Table 1 Properties of polypropylene (EH241)

Tablica 1. Svojstva polipropilena (EH241)

\begin{tabular}{|l|c|}
\hline \multicolumn{1}{|c|}{ Properties / Svojstva } & $\begin{array}{c}\text { Values } \\
\text { Vrijednost }\end{array}$ \\
\hline $\begin{array}{l}\text { Melt flow index, g/10 min (at } 230{ }^{\circ} \mathrm{C} / 2.16 \mathrm{~kg} \text { ) } \\
\text { indeks fluidnosti, } \mathrm{g} / 10 \mathrm{~min} \text { (pri } 230^{\circ} \mathrm{C} / 2,16 \mathrm{~kg} \text { ) }\end{array}$ & 5 to 20 \\
\hline Density / gustoća, $\mathrm{g} \cdot \mathrm{cm}^{-3}$ & 0.92 \\
\hline Water absorption / upijanje vode, $\%$ & 0.1 \\
\hline $\begin{array}{l}\text { Processing temperature / temperatura obrade, } \\
{ }^{\circ} \mathrm{C}\end{array}$ & $160-170$ \\
\hline Tensile modulus / modul elastičnosti, $\mathrm{MPa}$ & 35 \\
\hline Flexural modulus / modul savitljivosti, $\mathrm{GPa}$ & 1.5 \\
\hline $\begin{array}{l}\text { Izod Impact, notched / otpornost na udarce, } \\
\mathrm{kJ} \cdot \mathrm{m}^{-2}\end{array}$ & 2 \\
\hline
\end{tabular}


..... Sozen, Zor, Aydemir: The Effect of Nano TiO ${ }_{2}$ and Nano Boron Nitride on Mechanical...

Titanium dioxide $\left(\mathrm{TiO}_{2}\right)$ was supplied by mkNANO (Canada). Titanium dioxide nano powder (MKN$\mathrm{TiO}_{2}-015 \mathrm{P}$ : Hydrophilic $\mathrm{TiO}_{2}$ ) was amorphous and $99.5 \%$ pure. The size of $\mathrm{TiO}_{2}$ was $50 \mathrm{~nm}$. The specific surface area of titanium dioxide is $150 \mathrm{~m}^{2} \cdot \mathrm{g}^{-1}$.

Hexagonal boron nitride (hBN) was supplied by BORTEK - BOR Technologies, Inc. Boron nitride has the formula $\mathrm{BN}$, so it consists of boron and nitrogen elements. The hexagonal formation is stable and softest among the BN polymorphs. Boron nitrides cannot be naturally obtained, so they are chemically synthesized by reacting boron trioxide or boric acid with ammonia or urea (Rudolph 2000, Robert and Chaitanya 1990). The h-BN has a specific gravity of $2.27 \mathrm{~g} \cdot \mathrm{cm}^{-3}$ and a melting range of $2700-3000^{\circ} \mathrm{C}$. It consists of thin plates that have an average diameter of about $200 \mathrm{~nm}$ and a thickness of $80 \mathrm{~nm}$ (Ayrilmis et al., 2014).

\subsection{Methods}

\subsection{Metode}

WF was oven dried at $103 \pm 2{ }^{\circ} \mathrm{C}$ to obtain moisture content less than $1 \%$. PP was used as matrix polymer, while WF was used as fillers. Loading ratios of WF were 10 and $20 \%$ wt. Nano materials (nano $\mathrm{TiO}_{2}$ and nano boron nitride) loading level varied from 0.5 to $1 \%$ by compounding weight (1000 gr). A general survey of PP/WF compound after mechanical mixing is shown in Figure 1. The production formulations are given in Table 2.

The materials used in the compounding were first mixed to achieve better dispersion by mechanical mixer for 15 minute. The obtained samples were extruded at $50 \mathrm{rpm}$ by a single screw extruder. During the extrusion, the zone temperatures ranged from 170 to $180{ }^{\circ} \mathrm{C}$, the melting pressure of the extruder varied between 5 and 10 bars depending on material blends, the screw speed was $50 \mathrm{rpm}$, and the material output was $1 \mathrm{~kg} \cdot \mathrm{h}^{-1}$. When exiting the extrusion, the obtained compounds, which were melted, were cooled and solidified directly in a water-cooling system, while being pulled with end drive conveyors. Then, the solidified
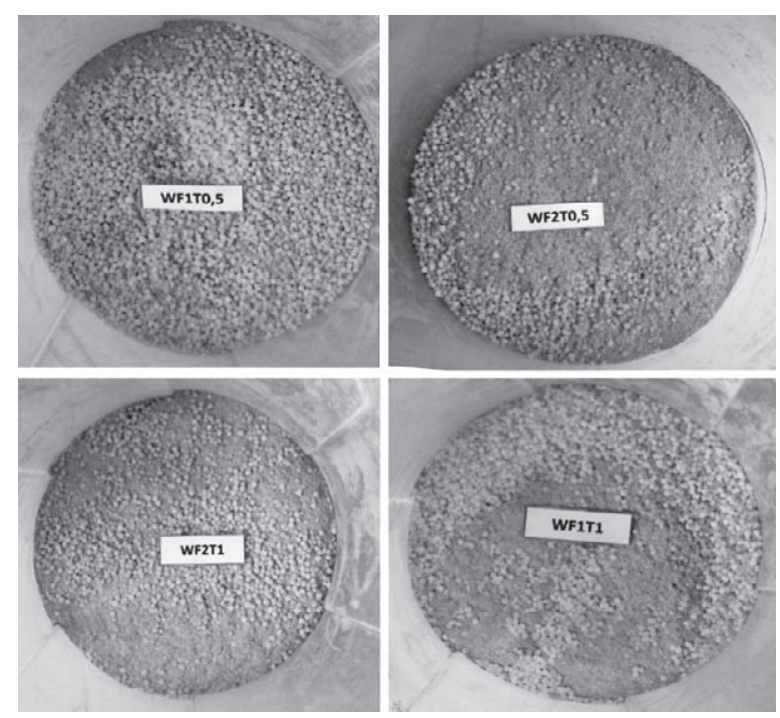

Figure 1 PP/WF compounds

Slika 1. Spojevi PP/WF
Table 2 Materials and ratios used in the study

Tablica 2. Materijali upotrijebljeni u eksperimentu i njihovi omjeri

\begin{tabular}{|l|c|c|c|c|}
\hline $\begin{array}{c}\text { Sample } \\
\text { code } \\
\text { Oznaka } \\
\text { uzorka }\end{array}$ & $\begin{array}{c}\text { Poly- } \\
\text { propyl- } \\
\text { ene } \\
\text { Polipro- } \\
\text { pilen } \\
\%\end{array}$ & $\begin{array}{c}\text { Filling } \\
\text { material } \\
\text { Punilo } \\
\%\end{array}$ & $\begin{array}{c}\text { Nano } \\
\text { material } \\
\text { Nanoma- } \\
\text { terijal } \\
\%\end{array}$ & $\begin{array}{c}\text { Type of } \\
\text { nano } \\
\text { material } \\
\text { Vrsta } \\
\text { nanoma- } \\
\text { terijala }\end{array}$ \\
\hline Neat PP & 100 & - & - & - \\
\hline PP+W1 & 90 & 10 & - & - \\
\hline PP+W2 & 80 & 20 & - & - \\
\hline PP+W1B0.5 & 89.5 & 10 & 0.5 & $\mathrm{BN}$ \\
\hline PP+W1B1 & 89. & 10 & 1 & $\mathrm{BN}$ \\
\hline PP+W1T0.5 & 89.5 & 10 & 0.5 & $\mathrm{TiO}_{2}$ \\
\hline PP+W1T1 & 89. & 10 & 1 & $\mathrm{TiO}_{2}$ \\
\hline PP+W2B0.5 & 79.5 & 20 & 0.5 & $\mathrm{BN}$ \\
\hline PP+W2B1 & 79 & 20 & 1 & $\mathrm{BN}$ \\
\hline PP+W2T0.5 & 79.5 & 20 & 0.5 & $\mathrm{TiO}_{2}$ \\
\hline PP+W2T1 & 79 & 20 & 1 & $\mathrm{TiO}_{2}$ \\
\hline
\end{tabular}

materials were pelletized through a pelletizer. The pellets obtained were injection molded to obtain the test samples. All samples were conditioned at $20^{\circ} \mathrm{C}$ and 65 $\%$ relative humidity prior to tests. First, the weights of samples $(m)$ were measured by $0.001 \mathrm{~g}$ precision scales. Sample volumes $(V)$ were calculated using dimensions and densities $(D)$ of samples determined according to $D=m / V$ equation.

The samples were air dried at $70{ }^{\circ} \mathrm{C}$ until a constant weight was reached prior to the immersion in a water bath. The specimens were periodically taken out of the water, wiped with tissue paper to remove surface water, reweighed and measured again and immediately put back into the water. The water absorption of the composites was determined according to ASTM D 1037-93.

Bending strength $(B M O R)$, flexure modulus $(B M O E)$, tensile strength $(T M O R)$ and tensile modulus (TMOE) were determined according to ASTM D 79003 Test Method 1 and ASTM D 638-03 Type I, respectively. These tests were conducted using a Zwick tester with a 10-kN load cell capacity. Test speed was used at a rate of $0.2 \mathrm{inch} \cdot \mathrm{min}^{-1}$ for all tests. The izod impact strength (IIS) tests were conducted according to ASTM D 256-06. The notches were provided with a NotchVIS machine (Ceast trademark) and tests were performed with a Resil $50 \mathrm{~B}$ impact tester. The morphological properties of the samples were observed with a scanning electron microscope (SEM) (TESCAN MAIA3) with an accelerating voltage of $15 \mathrm{kV}$ under nitrogen. The fracture parts of all samples were sputter-coated with gold using a Denton sputter coater for enhanced conductivity. The thermal stability of all the composites was investigated using a TGA and DSC (Perkin Elmer, TA Instruments, USA). When using a TGA, the samples were heated from $25{ }^{\circ} \mathrm{C}$ to $600{ }^{\circ} \mathrm{C}$ with a heating rate of $10^{\circ} \mathrm{C} / \mathrm{min}$ and a nitrogen flow of 100 $\mathrm{mL} \cdot \mathrm{min}^{-1}$. The samples weighing about $10 \mathrm{mg}$ were used for the tests. Degradation temperatures at $10 \%$ 
weight loss $\left(T_{10 \%}\right)$ and $50 \%$ weight loss $\left(T_{50 \%}\right)$, maximum degradation temperature in the derivative thermogravimetric peaks $\left(D T G_{\max }\right)$, and mass loss of the samples in the TGA curves were measured and compared with the results obtained.

One-way analysis of variance (ANOVA) was performed to identify significant differences at the 99 $\%$ confidence level. The Duncan test was used to determine the difference between groups. The important differences between formulations were shown with letters, such as A, B, C, and D.

\section{RESULTS AND DISCUSSION 3. REZULTATI I RASPRAVA}

\subsection{Physical and mechanical properties}

\subsection{Fizikalna i mehanička svojstva}

The highest density was determined to be 0.94 $\mathrm{g} \cdot \mathrm{cm}^{-3}$ in pure PP samples. This was followed, in order, by $\mathrm{PP}+\mathrm{W} 1 \mathrm{~B} 1, \mathrm{PP}+\mathrm{W} 1$ and $\mathrm{PP}+\mathrm{W} 1 \mathrm{~T} 1$ samples. The lowest density was obtained in the W2T1 sample. Low density of wood flour is the factor with the highest impact on decreasing densities. Densities of WFs used in the study varied between $0.40 \mathrm{~g} \cdot \mathrm{cm}^{-3}$ (Pinus nigra Arn.) and $0.63 \mathrm{~g} \cdot \mathrm{cm}^{-3}$ (Fagus orientalis L.). There is a significant difference in variations $\left(F_{\text {ratio }}=4.706 ; P_{\text {value }}\right.$ $=0.000<0.05)$ according to one-way analysis of the variance (ANOVA). Homogeneity within variations was determined by using Duncan test. Figure 2 and Table 3 show densities and homogeneity groups of WPC, respectively.

Figure 2 and Figure 3 show that the addition of wood flour increased $B M O R$ and $B M O E$ values. The highest value of $B M O R$ was found to be $51.60 \mathrm{MPa}$ in the PP+W1B1 samples. PP+W2B2 samples showed the highest BMOE with $2207 \mathrm{MPa}$ strength. Control samples (Pure PP) showed the lowest $B M O R$ value with $41.80 \mathrm{MPa}$ and $B M O E$ with $1256 \mathrm{MPa}$, respectively. Supporting WPC with wood flour resulted in the increase of $23.4 \%$ in the bending strength $(\mathrm{PP}+\mathrm{W} 1 \mathrm{~B} 1)$, $75 \%$ in the modulus of elasticity (PP+W2B1). Bouafif et al., (2009) state that lignocellulosic materials in-
Table 3 The homogeneity groups of WPC

Tablica 3. Homogene skupine drvno-plastičnih kompozita

\begin{tabular}{|l|l|l|}
\hline Sample code / Oznaka uzorka & \multicolumn{2}{|c|}{ Groups / Skupine } \\
\hline PP+WF1BN0.5 & 0.8665 & $\mathrm{~A}$ \\
\hline PP+WF1T0.5 & 0.8694 & $\mathrm{AB}$ \\
\hline PP+WF2 & 0.8764 & $\mathrm{ABC}$ \\
\hline PP+WF1T1 & 0.8915 & $\mathrm{ABCD}$ \\
\hline PP+WF2BN1 & 0.8928 & $\mathrm{BCD}$ \\
\hline PP+WF1 & 0.8930 & $\mathrm{BCD}$ \\
\hline PP+WF2T0.5 & 0.8989 & $\mathrm{CD}$ \\
\hline PP+WF2BN0.5 & 0.9029 & $\mathrm{D}$ \\
\hline PP+WF1BN1 & 0.9053 & $\mathrm{D}$ \\
\hline PP+WF2T1 & 0.9087 & $\mathrm{D}$ \\
\hline Pure PP & 0.9360 & $\mathrm{E}$ \\
\hline
\end{tabular}

creased the bending and tension strength as well as elasticity modules in bending and tension tests. BMOR and $B M O E$ values are shown in Figure 3 and Figure 4, respectively.

The multi-way ANOVA analysis was conducted to find the effects of nanoparticle type, nanoparticle rates and filler rate on bending strength of WPC and the obtained data are given in Table 4.

The effect of nanoparticle rate $(0.5 \%$ and $1 \%)$, nanoparticle type $\left(\mathrm{TiO}_{2}\right.$ and $\left.\mathrm{BN}\right)$ and filler rate $(10 \%$ and $20 \%$ ) on the BMOR was found to be significant according to the result of Duncan test as seen in Table 5. The effect of interaction of nanoparticle type and filler rate on the bending strength was statistically significant. Duncan test was applied to determine the differences between groups. The effects of nanoparticle rate, nanoparticle type and filler material rate on the bending strength are given in Table 5. Increasing in nanoparticle rate increased proportionally both $B M O R$ and $B M O E$ values (Table 5.1). BN increased the BMOR strength, while $\mathrm{TiO}_{2}$ contributed to the development of $B M O E$ strength. It can be said that $\mathrm{BN}$ is more effective in bending resistance when compared to $\mathrm{TiO}_{2}$ ( Table 5.2). Adding wood flour to pure PP increased the $B M O R$ and $B M O E$, but the filler rate was not important in BMOR test according to Table 5.3.

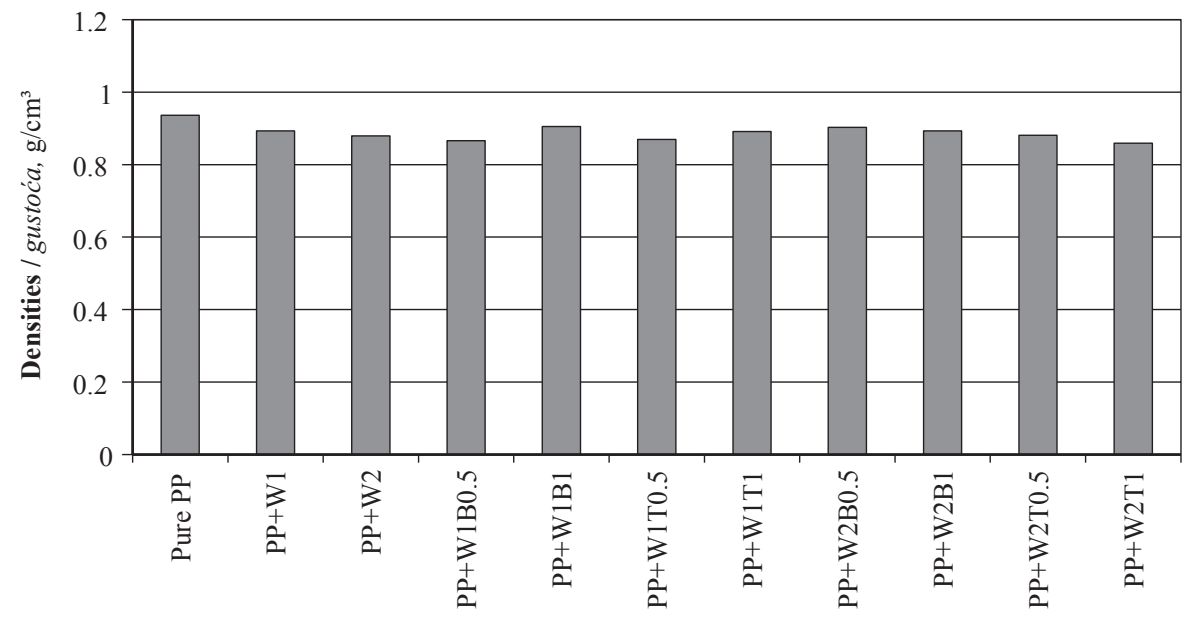

Wood polymer composites / drvno-plastični kompoziti

Figure 2 Densities of WPC

Slika 2. Gustoća istraživanih drvno-plastičnih kompozita 
..... Sozen, Zor, Aydemir: The Effect of Nano TiO ${ }_{2}$ and Nano Boron Nitride on Mechanical...

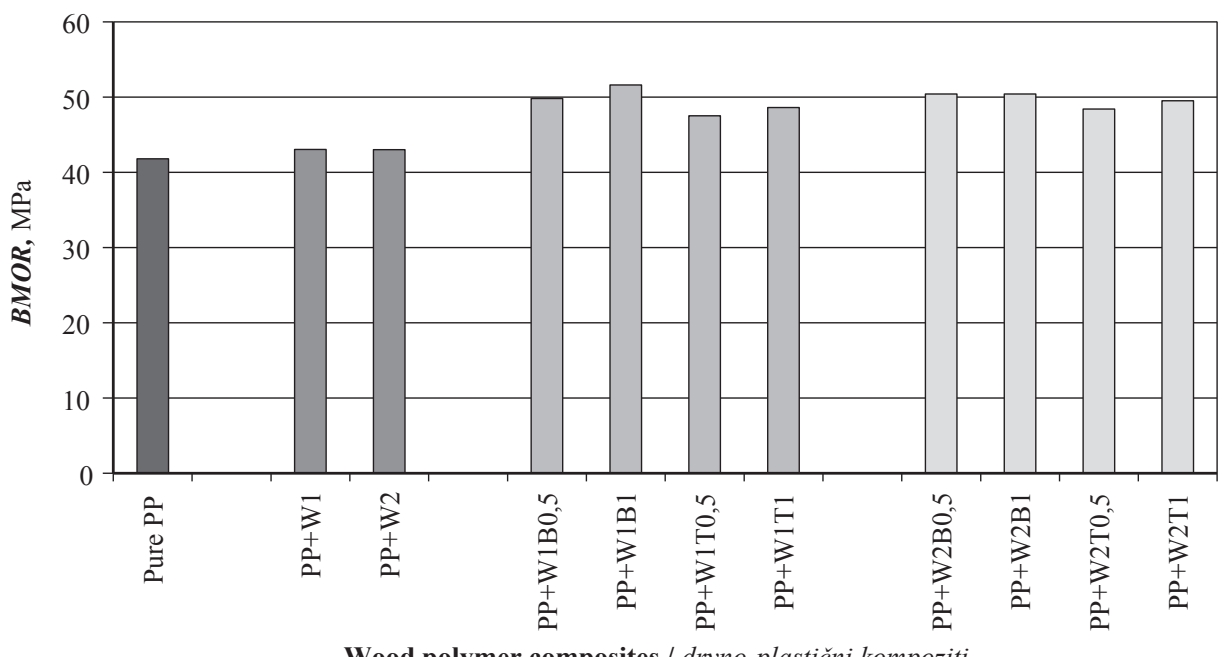

Wood polymer composites / drvno-plastični kompoziti

Figure $3 B M O R$ values of WPC

Slika 3. Čvrstoća na savijanje istraživanih drvno-plastičnih kompozita

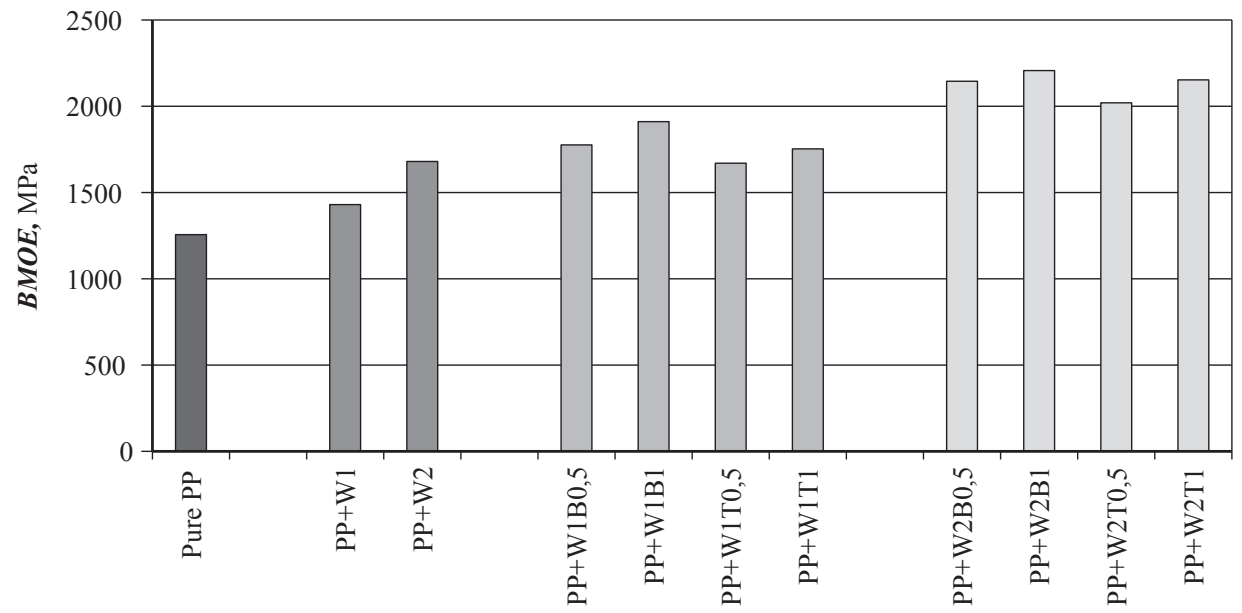

Wood polymer composites / drvno-plastični kompoziti

Figure $4 B M O E$ values of WPC

Slika 4. Modul elastičnosti pri savijanju istraživanih drvno-plastičnih kompozita

Table 4 Multi-way ANOVA analysis done for the effects of nanoparticle type, nanoparticle rate and filler rate on bending strength of WPC

Tablica 4. Višefaktorska ANOVA analiza utjecaja vrste nanočestica, količine nanočestica i količine punila na čvrstoću savijanja drvno-plastičnih kompozita

\begin{tabular}{|c|c|c|c|c|c|}
\hline Source / Izvor varijabilnosti & $\begin{array}{l}\text { Type III Sum of } \\
\text { Squares } \\
\text { Zbroj kvadrata }\end{array}$ & $d f$ & $\begin{array}{c}\text { Mean Square } \\
\text { Srednja vrijednost } \\
\text { kvadrata }\end{array}$ & $\boldsymbol{F}$ & Sig. \\
\hline Corrected model / korigirani model & $575.056^{\mathrm{a}}$ & 10 & 57.506 & 85.748 & .000 \\
\hline Intercept / presjek & 114171.222 & 1 & 114171.222 & $1.702 \mathrm{E} 5$ & .000 \\
\hline Filler rate $(\mathrm{A}) /$ udjel punila $(A)$ & 5.040 & 2 & 2.520 & 3.757 & .031 \\
\hline Nanoparticle type (B) / vrsta nanočestica (B) & 40.381 & 1 & 40.381 & 60.213 & .000 \\
\hline $\begin{array}{l}\text { Nanoparticle rate }(\mathrm{C}) \\
\text { količina nanočestica }(\mathrm{C})\end{array}$ & 8.621 & 1 & 8.621 & 12.855 & .001 \\
\hline$(\mathrm{A}) *(\mathrm{~B})$ & 4.363 & 1 & 4.363 & 6.505 & .014 \\
\hline$(\mathrm{A}) *(\mathrm{C})$ & 2.093 & 1 & 2.093 & 3.121 & .084 \\
\hline$(\mathrm{B}) *(\mathrm{C})$ & 0.281 & 1 & 0.281 & 0.418 & .521 \\
\hline$(\mathrm{A}) *(\mathrm{~B}) *(\mathrm{C})$ & 2.678 & 1 & 2.678 & 3.993 & .052 \\
\hline Error / pogreška & 29.508 & 44 & 0.671 & & \\
\hline Total / ukupno & 125208.989 & 55 & & & \\
\hline Corrected Total / ispravljeno ukupno & 604.564 & 54 & & & \\
\hline
\end{tabular}


Sozen, Zor, Aydemir: The Effect of Nano TiO 2 and Nano Boron Nitride on Mechanical... .....

Table 5 Effect of nanoparticle rate (A), nanoparticle type (B) and filler rate (C) on BMOR according to Duncan test

Tablica 5. Utjecaj količine nanočestica (A), vrste nanočestica (B) i količine punila (C) na čvrstoću na savijanje istraživanih kompozitnih materijala prema Duncanovu testu

\begin{tabular}{|l|c|c|c|}
\hline \multirow{2}{*}{$\begin{array}{c}\text { Nanoparticle } \\
\text { rate / Količina } \\
\text { nanočestica }\end{array}$} & \multicolumn{3}{|c|}{ Groups / Skupine } \\
\cline { 2 - 4 } & $\mathrm{A}$ & $\mathrm{B}$ & $\mathrm{C}$ \\
\hline Control & 42.61 & & \\
\hline $0.5 \%$ & & 49.00 & \\
\hline $1 \%$ & & & 49.92 \\
\hline
\end{tabular}

A)

\begin{tabular}{|l|c|c|c|}
\hline \multirow{2}{*}{$\begin{array}{c}\text { Nanoparticle } \\
\text { type / Vrsta } \\
\text { nanočestica }\end{array}$} & \multicolumn{3}{|c|}{ Groups / Skupine } \\
\cline { 2 - 4 } & $\mathrm{A}$ & $\mathrm{B}$ & $\mathrm{C}$ \\
\hline Control & 42.61 & & \\
\hline $\mathrm{TiO}_{2}$ & & 48.46 & \\
\hline $\mathrm{BN}$ & & & 50.46 \\
\hline
\end{tabular}

B)

\begin{tabular}{|l|c|c|}
\hline \multirow{2}{*}{$\begin{array}{c}\text { Filler } \\
\text { rate } \\
\text { Količina punila }\end{array}$} & \multicolumn{2}{|c|}{$\begin{array}{c}\text { Groups } \\
\text { Skupine }\end{array}$} \\
\cline { 2 - 3 } & $\mathrm{A}$ & $\mathrm{B}$ \\
\hline Control & 41.82 & \\
\hline $10 \%$ & & 48.07 \\
\hline $20 \%$ & & 48.27 \\
\hline
\end{tabular}

C)

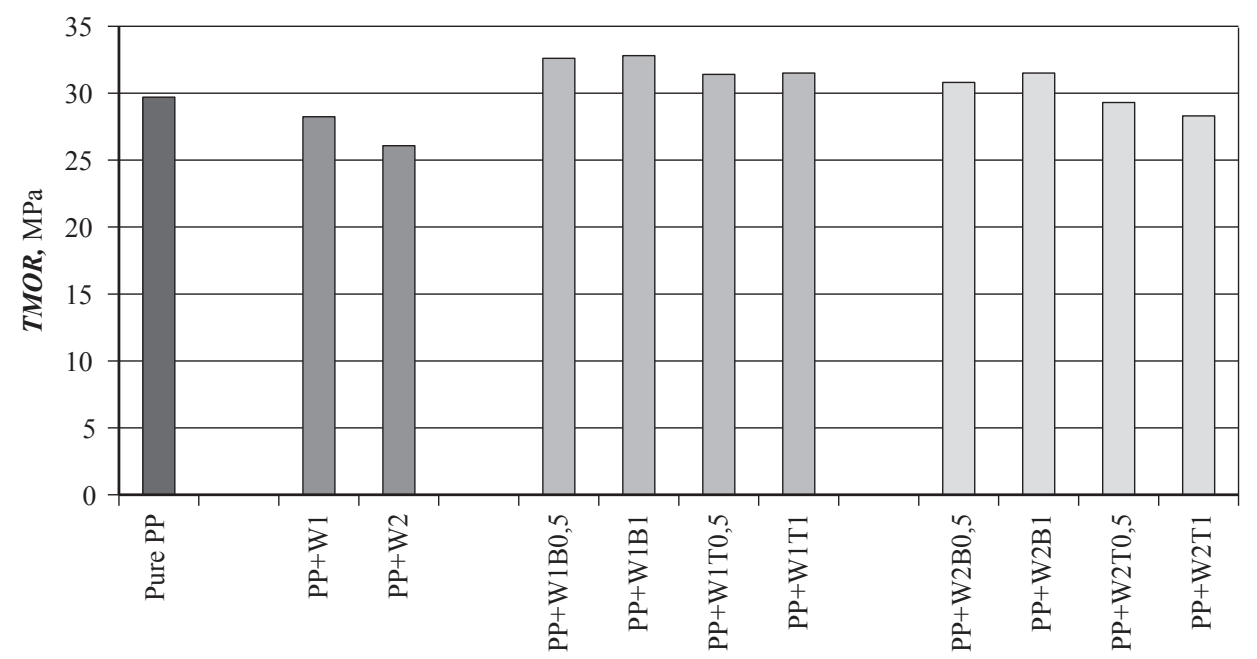

Wood polymer composites / drvno-plastični kompoziti

Figure $5 T M O R$ values of WPC

Slika 5. Vlačna čvrstoća istraživanih drvno-plastičnih kompozita

Figure 5 and Figure 6 show TMOR and TMOE values of the samples, respectively. TMOR of pure PP was determined as 29.7 MPa. Decreasing was observed in TMOR values of $\mathrm{PP}+\mathrm{W} 1$ and $\mathrm{PP}+\mathrm{W} 2$ samples. These decreases were calculated to be $4.94 \%$ and 12.2 $\%$, respectively. All samples containing nano boron nitride showed increased TMOR values when compared to control samples. TMOE of pure PP increased in all of the samples. The highest increase in TMOE of
$\mathrm{PP}+\mathrm{W} 2 \mathrm{~B} 1$ and $\mathrm{PP}+\mathrm{W} 2 \mathrm{~B} 0.5$ was determined to be 83 $\%$ and $75.8 \%$, respectively.

According to the multi-way ANOVA analysis, it was found that the filler rate (A), nanoparticle type (B) and nanoparticle rate $(\mathrm{C})$ were statistically significant at 0.05 . Table 6 shows the results of multi-way ANOVA analysis.

It was found that the interaction between filler rate (1) and nanoparticle rate (3) was not significant. In-

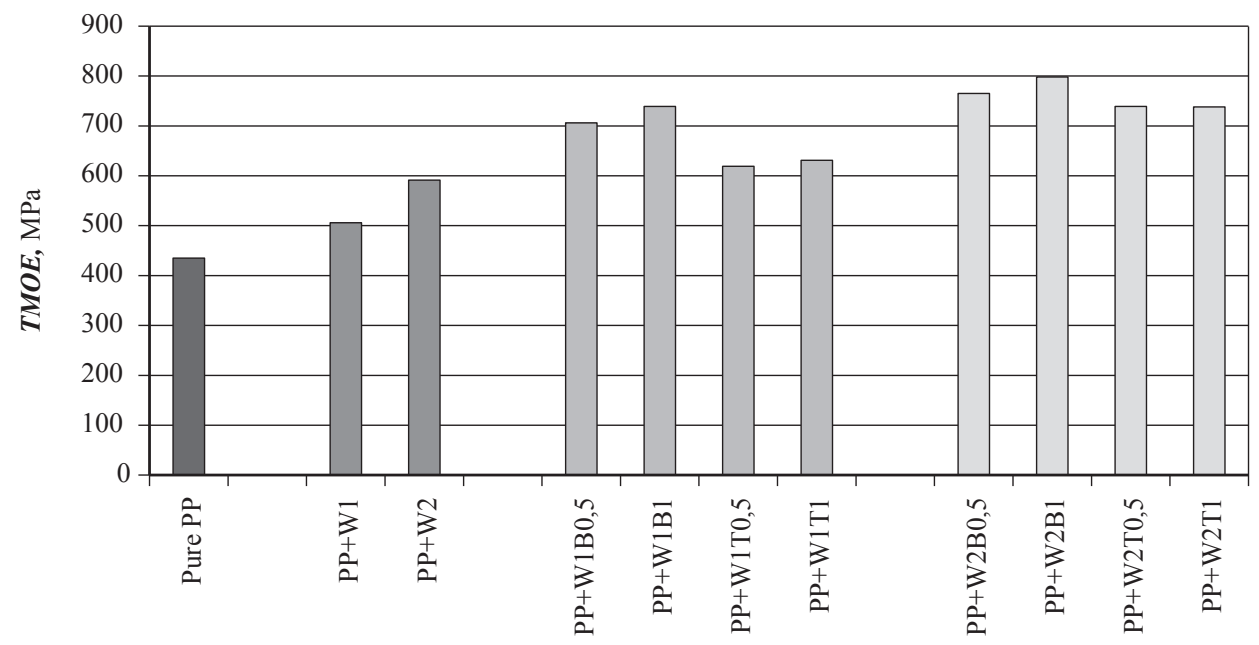

Wood polymer composites / drvno-plastični kompoziti

Figure 6 TMOE values of WPC

Slika 6. Vlačni modul elastičnosti istraživanih drvno-plastičnih kompozita 
..... Sozen, Zor, Aydemir: The Effect of Nano TiO ${ }_{2}$ and Nano Boron Nitride on Mechanical...

Table 6 Multi-way ANOVA analysis determining the effects of nanoparticle type, nanoparticle rate and filler rate on tensile strength of WPC

Tablica 6. Višefaktorska ANOVA analiza utjecaja vrste nanočestica, količine nanočestica i količine punila na vlačnu čvrstoću drvno-plastičnih kompozita

\begin{tabular}{|l|c|c|c|c|c|}
\hline \multicolumn{1}{|c|}{ Source / Izvor varijabilnosti } & $\begin{array}{c}\text { Type III Sum of } \\
\text { Squares } \\
\text { Zbroj kvadrata }\end{array}$ & $\boldsymbol{d f}$ & $\begin{array}{c}\text { Mean Square } \\
\text { Srednja vrijednost } \\
\text { kvadrata }\end{array}$ & $\boldsymbol{F}$ & Sig. \\
\hline Corrected model / korigirani model & $216.347^{\mathrm{a}}$ & 10 & 21.635 & 94.949 & .000 \\
\hline Intercept / presjek & 46710.972 & 1 & 46710.972 & $2.050 \mathrm{E} 5$ & .000 \\
\hline Filler rate (A) / udjel punila (A) & 76.101 & 2 & 38.051 & 166.994 & .000 \\
\hline Nanoparticle type (B) / vrsta nanočestica (B) & 32.256 & 1 & 32.256 & 141.564 & .000 \\
\hline Nanoparticle rate (C) / količina nanočestica (C) & .018 & 1 & 0.018 & .081 & .777 \\
\hline (A)*(B) & 2.948 & 1 & 2.948 & 12.940 & .001 \\
\hline (A) $*(C)$ & .331 & 1 & 0.331 & 1.454 & .234 \\
\hline (B)*(C) & 2.116 & 1 & 2.116 & 9.287 & .004 \\
\hline$(\mathrm{A}) *(B) *(C)$ & 1.706 & 1 & 1.706 & 7.486 & .009 \\
\hline Error / Pogreška & 10.026 & 44 & 0.228 & & \\
\hline Total / Ukupno & 50316.722 & 55 & & & \\
\hline Corrected Total / ispravljeno ukupno & 226.373 & 54 & & & \\
\hline
\end{tabular}

creasing the rate of wood flour decreased the tensile strength of WPC when compared to control samples. However, adding nanoparticles to WF/PP compound led to a significant increase. It can be said that $\mathrm{BN}$ provided a better fit with wood flour than $\mathrm{TiO}_{2}$. The effects of nanoparticle rate (1), nanoparticle type (2) and filler rate (3) on the TMOR are according to the results of Duncan test. The related test results are shown in Table 7.
As seen in Figure 7, the highest izod impact strength (IIS) was obtained in $\mathrm{PP}+\mathrm{W} 1$ and $\mathrm{PP}+\mathrm{W} 2$ samples, $2.17 \mathrm{~kJ} \cdot \mathrm{m}^{-2}$ and $2.07 \mathrm{~kJ} \cdot \mathrm{m}^{-2}$, respectively. The lowest IIS was determined in W1samples, which contained $0.5 \%$ of nano boron nitride. Generally, it can be said that nanoparticles decreased the izod impact strength of WF/PP composites.

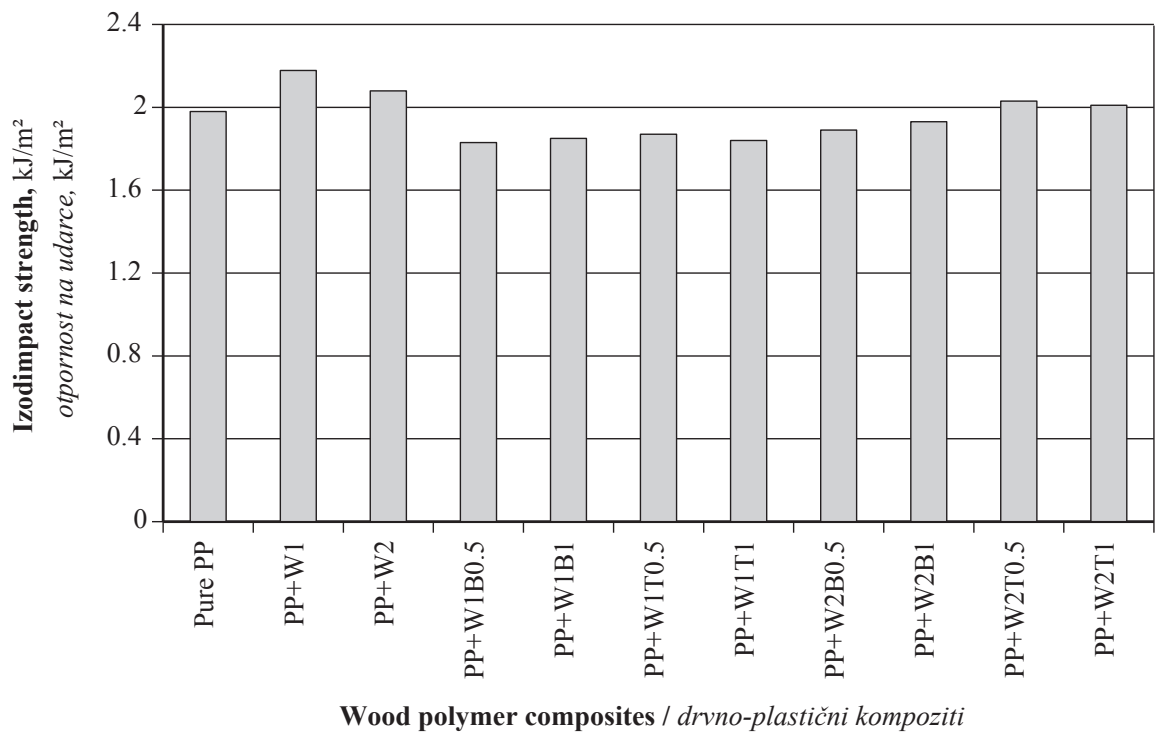

Figure 7 Izod impact strength (IIS) values of WPC

Slika 7. Otpornost na udarce (IIS) istraživanih drvno-plastičnih kompozita

Table 7 Effect of nanoparticle rate (A), nanoparticle type (B) and filler rate (C) on TMOR according to Duncan test Tablica 7. Utjecaj količine nanočestica (A), vrste nanočestica (B) i količine punila (C) na vlačnu čvrstoću istraživanih kompozitnih materijala prema Duncanovu testu

\begin{tabular}{|l|c|c|}
\hline \multirow{2}{*}{$\begin{array}{c}\text { Nanoparticle } \\
\text { rate }\end{array}$} & \multicolumn{2}{c|}{$\begin{array}{c}\text { Groups } \\
\text { Skupine }\end{array}$} \\
\cline { 2 - 3 } Količina nanočestica & $\mathrm{A}$ & $\mathrm{B}$ \\
\hline Control & 27.99 & \\
\hline $0.5 \%$ & & 30.97 \\
\hline $1 \%$ & & 31.01 \\
\hline
\end{tabular}

A)

\begin{tabular}{|l|c|c|c|}
\hline \multirow{2}{*}{$\begin{array}{c}\text { Nanoparticle } \\
\text { type }\end{array}$} & \multicolumn{3}{|c|}{$\begin{array}{c}\text { Groups } \\
\text { Skupine }\end{array}$} \\
\cline { 2 - 4 } Vrsta nanočestica & $\mathrm{A}$ & $\mathrm{B}$ & $\mathrm{C}$ \\
\hline Control & 27.99 & & \\
\hline $\mathrm{TiO}_{2}$ & & 30.09 & \\
\hline $\mathrm{BN}$ & & & 31.89 \\
\hline
\end{tabular}

B)

\begin{tabular}{|l|c|c|}
\hline \multirow{2}{*}{$\begin{array}{c}\text { Filler rate } \\
\text { Količina punila }\end{array}$} & \multicolumn{2}{|c|}{$\begin{array}{c}\text { Groups } \\
\text { Skupine }\end{array}$} \\
\cline { 2 - 3 } & $\mathrm{A}$ & $\mathrm{B}$ \\
\hline $20 \%$ & 29.15 & \\
\hline Control & 29.68 & \\
\hline $10 \%$ & & 31.30 \\
\hline
\end{tabular}

C) 


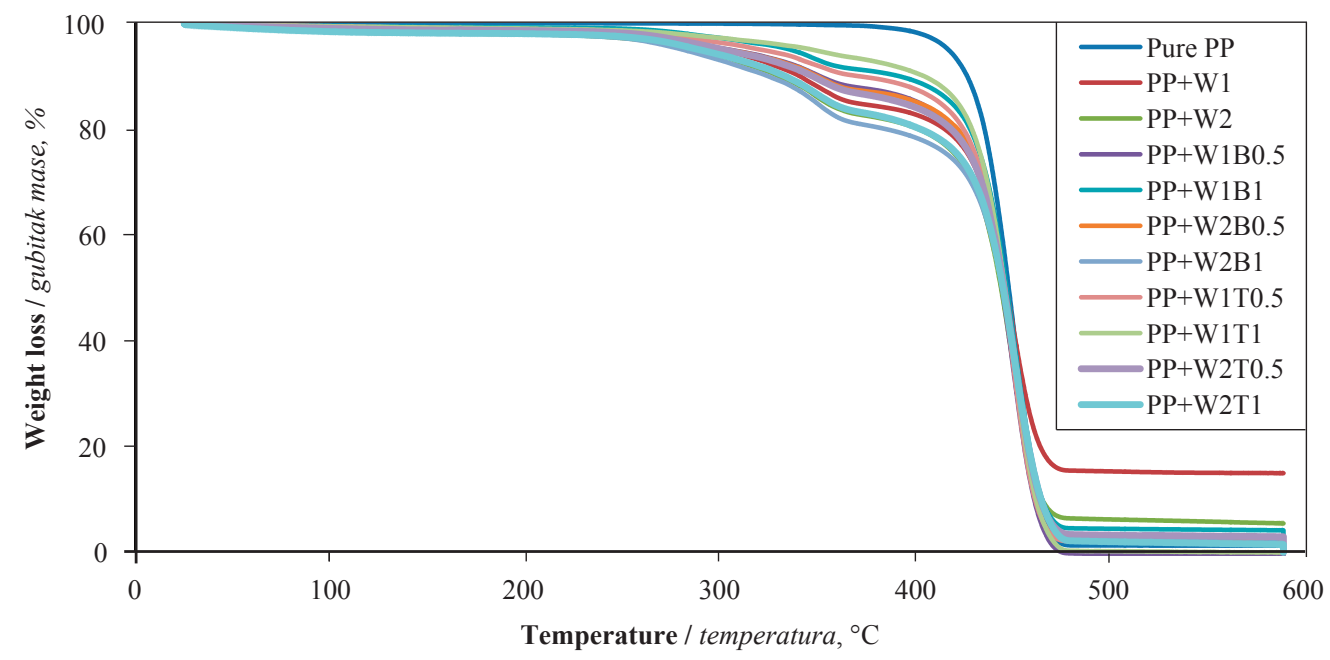

Figure 8 TGA curves of WPC

Slika 8. TGA krivulje istraživanih drvno-plastičnih kompozita

\subsection{Thermal Characterization}

\subsection{Toplinska svojstva}

Thermal stability of the samples was investigated using TGA/DTG analysis. As sees in Fig 8, it can be said that no significant difference occured in TGA analysis with the addition of nanoparticle types and filler. The fastest mass losses were observed in samples containing $\mathrm{PP}+\mathrm{W} 2 \mathrm{~T} 1$ and $\mathrm{PP}+\mathrm{W} 2 \mathrm{NB} 1$. On the other hand, the PP+W1T1 curve was the nearest to the curve of pure PP. Onset temperature of the composites was also determined to decrease with adding the nanoparticle types and filler. Similarly, as the filler loading increased, the thermal stability of the composites slightly decreased, whereas the final ash content monotonically increased (Kiziltas et al., 2011a, b).

DTG curves in Figure 9 showed maximum degradation at $453{ }^{\circ} \mathrm{C}$ for $\mathrm{W} 2 \mathrm{NB} 1 \%$, and the peaks of the composites were found to be between $350{ }^{\circ} \mathrm{C}$ and 470 ${ }^{\circ} \mathrm{C}$. As seen in Table 8, DTA curves indicated the two peaks of melting peak $\left(T_{\mathrm{m}}\right)$ and decomposition peak $\left(T_{\mathrm{d}}\right)$. It is well known that PP, which is extremely hyg- roscopic in nature, is consumed at $426{ }^{\circ} \mathrm{C}$ without formation of any char residue (Baeza and Freer, 2001).

As seen in Table 8, the maximum value of $T_{\mathrm{m}}$ was found in the wood composites with $1 \% \mathrm{NB}\left(167.5^{\circ} \mathrm{C}\right)$, whereas the minimum value of $T_{\mathrm{m}}$ was determined in the wood composites with $1 \%$ NB. $T_{\mathrm{d}}$ values, the maximum and minimum values, were found to be $1 \% \mathrm{NB}$ and $0.5 \% \mathrm{~T}$, respectively. The summary of the thermogravimetric analysis is presented in Table 8.

\section{CONCLUSIONS}

4. ZAKLJUČAK

Adding wood flour has no significant effect on the density of WPC composites. The BMOR and BMOE of the composites were increased both with the addition of wood flour and nanoparticle rate. The TMOR, TMOE and izod impact strength of the composites were negatively affected by the increase of the rate of wood flour. It was found that thermal stability of the composites (TGA) decreased with both nanoparticle

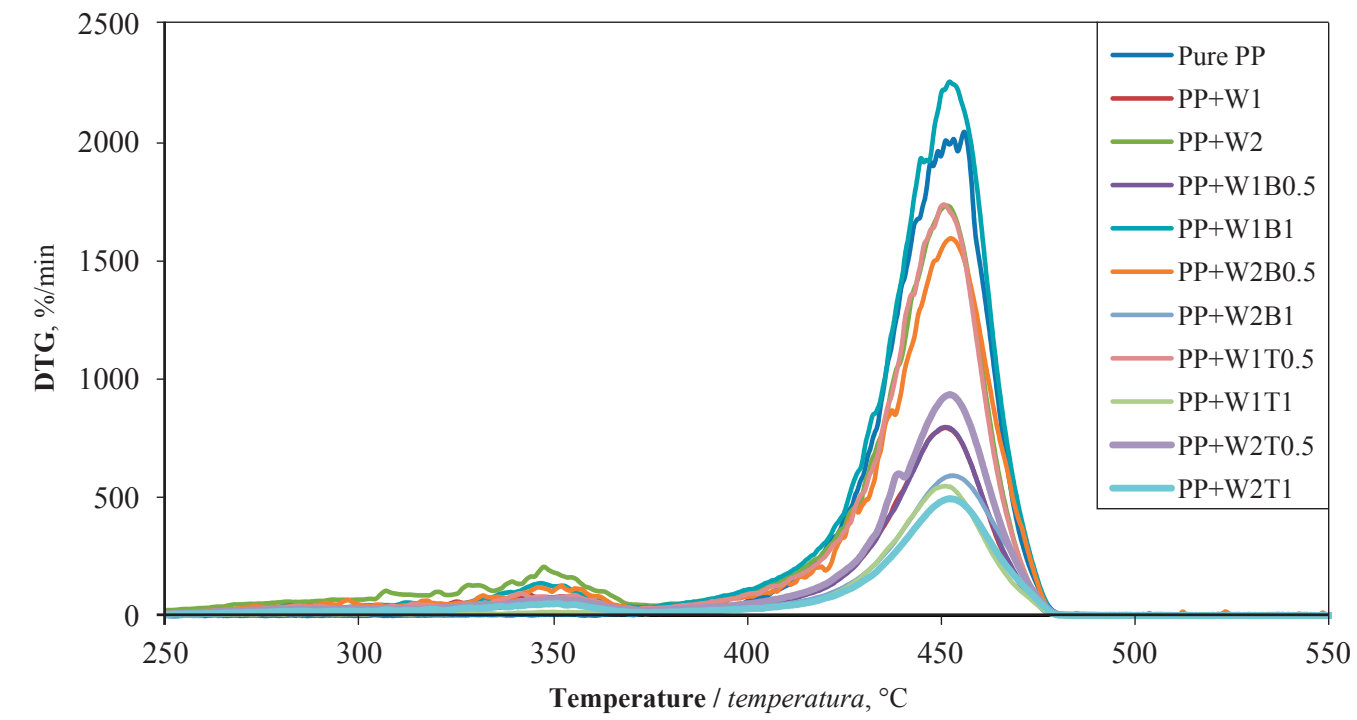

Figure 9 DTG curves of WPC

Slika 9. DTG krivulje istraživanih drvno-plastičnih kompozita 
..... Sozen, Zor, Aydemir: The Effect of Nano TiO ${ }_{2}$ and Nano Boron Nitride on Mechanical...

Table 8 Summary of thermogravimetric analysis

Tablica 8. Sažetak termogravimetrijske analize

\begin{tabular}{|l|c|c|c|c|c|c|c|}
\hline $\begin{array}{l}\text { Samples } \\
\text { Uzorci }\end{array}$ & $\begin{array}{c}\boldsymbol{T}_{\mathbf{1 0 \%}} \\
{ }^{\circ} \mathrm{C}\end{array}$ & $\begin{array}{c}\boldsymbol{T}_{\mathbf{5 0 \%}} \\
{ }^{\circ} \mathrm{C}\end{array}$ & $\begin{array}{c}\boldsymbol{T}_{\mathbf{9 0 \%}} \\
{ }^{\circ} \mathrm{C}\end{array}$ & $\begin{array}{c}\text { Residue } \\
\boldsymbol{\%}^{\circ}\end{array}$ & $\begin{array}{c}\boldsymbol{D} \boldsymbol{T G}_{\mathbf{m a x}} \\
{ }^{\circ} \mathrm{C}\end{array}$ & $\begin{array}{c}\boldsymbol{T}_{\mathbf{m}} \\
{ }^{\circ} \mathrm{C}\end{array}$ & $\begin{array}{c}\boldsymbol{T}_{\mathbf{d}} \\
{ }^{\circ} \mathrm{C}\end{array}$ \\
\hline PP & 427.0 & 448.3 & 463.3 & 98.7 & 456.0 & 166.4 & 450.3 \\
\hline PP+W1 & 341.18 & 447.15 & 465.3 & 84.9 & 451.0 & 158 & 448.2 \\
\hline PP+W2 & 330.22 & 444.39 & 465.4 & 94.7 & 451.5 & 159.6 & 451.2 \\
\hline PP+W1B0.5 & 351.4 & 444.9 & 461.4 & 99.8 & 451.1 & 163.4 & 450.9 \\
\hline PP+W1B1 & 392.2 & 447.2 & 465.4 & 95.9 & 452.1 & 167.5 & 451.5 \\
\hline PP+W2NB0.5 & 350.2 & 446.3 & 464.6 & 98.0 & 452.6 & 165.6 & 452.3 \\
\hline PP+W2NB1 & 324.9 & 445.2 & 465.5 & 98.2 & 453.0 & 161.8 & 456.4 \\
\hline PP+W1T0.5 & 371.6 & 445.4 & 461.8 & 98.3 & 450.7 & 165.9 & 450.1 \\
\hline PP+W1T1 & 404.9 & 446.3 & 463.0 & 99.8 & 451.0 & 162.3 & 450.5 \\
\hline PP+W2T0.5 & 347.6 & 445.9 & 464.6 & 97.1 & 452.2 & 164.4 & 451.4 \\
\hline PP+W2T1 & 333.6 & 445.4 & 464.9 & 98.5 & 452.1 & 163.1 & 455.8 \\
\hline
\end{tabular}

types. It was concluded that wood flour obtained from particleboards in WPCs has a significant effect on the material characterization (mechanical properties, thermal properties, etc.). Based on the findings obtained from the present study, the use of W1T1 can further increase mechanical performance of all composites.

\section{REFERENCES}

\section{LITERATURA}

1. Ashori, A., 2008: Wood-plastic composites as promising green-composites for automotive industries. Bioresources Technology, 99 (11): 4661-4667.

https://doi.org/10.1016/j.biortech.2007.09.043.

2. Aydemir, D.; Kiziltas, A.; Kiziltas, E. E.; Gardner, D. J.; Gunduz, G., 2015: Heat treated wood-nylon 6 composites. Composites Part B: Engineering, 68: 414-423. https://doi.org/10.1016/j.compositesb.2014.08.040.

3. Ayrilmis, N.; Dundar, T.; Kaymakci, A.; Ozdemir, F.; Kwon, J. H., 2014: Mechanical and Thermal Properties of Wood-Plastic Composites Reinforced With Hexagonal Boron Nitride. Polymer composites, 35 (1): 194-200. https://doi.org/10.1002/pc.22650.

4. Baeza, J.; Freer, J., 2001: Chemical characterization of wood and its components. In: Hon, D. N. S. \& Shiraishi, N. (eds.). Wood and cellulosic chemistry. Marcel Dekker Inc., New York, pp. 275-384.

5. Bardak, T.; Tankut. A. N.; Tankut. N.; Sozen, E.; Aydemir, D., 2016: The effect of nano- $\mathrm{TiO}_{2}$ and $\mathrm{SiO}_{2}$ on bonding strength and structural properties of poly (vinyl acetate) composites. Measurement, 93: 80-85.

https://doi.org/10.1016/j.measurement.2016.07.004.

6. Bledzki, A. K.; Gassan, J., 1999: Composites reinforced with cellulose based fibers. Progress in Polymer Science, 24 (2): 221-274.

https://doi.org/10.1016/S0079-6700(98)00018-5.

7. Bouafif, H.; Ahmed, K.; Patrick, P.; Alain, C., 2009: Effects of fiber characteristics on the physical and mechanical properties of wood plastic composites. Composites Part A: Applied Science and Manufacturing, 40 (12): 1975-1981.

https://doi.org/10.1016/j.compositesa.2009.06.003.

8. Deka, B. K.; Maji, T. K., 2011: Effect of $\mathrm{TiO}_{2}$ and nanoclay on the properties of wood polymer nanocomposite. Composites Part A: Applied Science and Manufacturing, 42 (12): 2117-2125. https://doi.org/10.1016/j.compositesa.2011.09.023.

9. Garcia, M.; Hidalgo, J.; Garmendia, I.; García-Jaca, J., 2009: Wood-plastics composites with better fire retar- dancy and durability performance. Composites Part A: Applied Science and Manufacturing, 40 (11): 1772-1776. https://doi.org/10.1016/j.compositesa.2009.08.010.

10. Jung, J.; Kim, J.; Uhm, Y. R.; Jeon, J. K.; Lee, S.; Lee, H. M.; Rhee, C. K., 2010: Preparations and thermal properties of micro-and nano-BN dispersed HDPE composites. Thermochimica acta, 499 (1): 8-14. https://doi.org/10.1016/j.tca.2009.10.013.

11. Kiziltas, A.; Gardner, D. J.; Han, Y.; Yang, H.-S., 2011a: Thermal properties of microcrystalline cellulose-filled PET - PTT blend polymer composites. Journal of Thermal Analysis and Calorimetry, 103 (1): 163-170. https://doi.org/10.1007/s10973-010-0894-6.

12. Kiziltas, A.; Gardner, D. J.; Han, Y.; Yang, H. S., 2011b: Dynamic mechanical behavior and thermal properties of microcrystalline cellulose (MCC)-filled nylon 6 composites. Thermochimica Acta, 519 (1-2): 38-43. https://doi.org/10.1016/j.tca.2011.02.026.

13. Meneghetti, P.; Hans, P. J.; Shaffer, G. W., 2008: Enhanced boron nitride composition and polymer-based compositions made therewith. Patent; US7445797.

14. Mirabedini, S. M.; Mohseni, M.; PazokiFard, S.; Esfandeh, M., 2008: Effect of $\mathrm{TiO}_{2}$ on the mechanical and adhesion properties of RTV silicone elastomer coatings. Colloids Surf A: Physicochem Eng Aspects, 317 (1-3): 80-86. https://doi.org/10.1016/j.colsurfa.2007.09.044.

15. Nayak, R. K.; Mahato, K. K.; Ray, B. C., 2016: Water absorption behavior. mechanical and thermal properties of nano $\mathrm{TiO}_{2}$ enhanced glass fiber reinforced polymer composites. Composites Part A: Applied Science and Manufacturing, 90: 736-747. https://doi.org/10.1016/j. compositesa.2016.09.003.

16. Okamoto, T., 2003: Recent developments in wood/plastic composites - Extrusion of wood-based materials. Mokuzai Gakkaishi, 49 (6): 401-407.

17. Osswald, T. A.; Menges, G., 1995: Materials science of polymers for engineers. Carl Hanser Verlag $\mathrm{GmbH}$ Co KG. Munich.

18. Park, E. S., 2008: Morphology. mechanical and dielectric breakdown properties of PBT/PET/TPE, PBT/PET/ PA66, PBT/PET/LMPE and PBT/PET/TiO 2 blends. Polymer Composites, 29 (10): 1111-1118. https://doi.org/10.1002/pc.20626.

19. Robert, T. P.; Chaitanya, K. N., 1990: Synthetic Routes to Boron Nitride. Chemical Reviews, 90: 73-91. https://doi.org/10.1021/cr00099a004.

20. Rowell, R. M.; Sanadi, A. R.; Caulfield, D. F.; Jacobson, R. E., 1997: Utilization of natural fibers in plastic composites: problems and opportunities. LignocellulosicPlastic Composites, 23-51. 
Sozen, Zor, Aydemir: The Effect of Nano TiO ${ }_{2}$ and Nano Boron Nitride on Mechanical...

21. Rudolph, S., 2000: Boron Nitride (BN). American Ceramic Society Bulletin, 79: 50.

22. Sobczak, L.; Brüggemann, O.; Putz, R. F., 2013: Polyolefin composites with natural fibers and wood-modification of the fiber/filler-matrix interaction. Journal of Application Polymer Science, 127 (1): 1-17. https://doi.org/10.1002/app.36935.

23. Soccalingame, L.; Perrin. D.; Bénézet. J. C.; Bergeret, A., 2016: Reprocessing of UV-weathered wood flour reinforced polypropylene composites: Study of a natural outdoor exposure. Polymer Degradation and Stability, 133: 389-398.

http://dx.doi.org/10.1016/j.polymdegradstab.2016.09.011.

24. Wittig, W., 1994: Kunststoffe im Automobilbau, VDIVerlag, Dusseldorf.

25. Zhou, W.; Qi, S.; Li, H.; Shao, S., 2007: Study on insulating thermal conductive BN/HDPE composites. Thermochimica Acta, 452 (1): 36-42.

https://doi.org/10.1016/j.tca.2006.10.018.
26. Zor, M.; Tankut, N.; Kızıltaş, A.; Gardner, D. J.; Yazııı, H., 2017: Feasibility of Using Foamed Styrene Maleic Anhydride (SMA) Co-polymer in Wood Based Composites, Drvna industrija, 67 (4): 399-407.

https://doi.org/10.5552/drind.2016.1624.

\section{Corresponding address:}

MUSTAFA ZOR, Ph. D.

Department of Material and Material Processing Technology

Caycuma Vocational School

University of Bulent Ecevit 67900

Caycuma/Zonguldak, TURKEY

e-mail: mustafa.zor@beun.edu.tr 